\title{
THE ANALYSIS OF THE EMPLOYEE SELECTION PROCESS IN ORGANIZATIONS IN CENTRAL SERBIA
}

\author{
Savić Tot Tijana ${ }^{1}$ \\ Runić Ristić Marija $^{2}$ \\ Adžić Slobodan ${ }^{3}$
}

\begin{abstract}
The employee selection process represents one of the most delicate human resource management fun4ctions. Since the main purpose of the selection process is to attract and hire candidates who are going to fulfill the needs of an organization, the paper aims to analyze the characteristics of the selection process in organizations in Central Serbia. The problem of the research is to identify differences in the selection process among organizations that have different activities, legal forms, and the number of employees. The basic hypothesis that states that there are statistically significant differences in the selection process in studied organizations. The research results show, among other things, the deficiencies in the employee selection process, as well as the differences in the employee selection process in organizations that conduct different
\end{abstract}

\footnotetext{
${ }^{1}$ Fakultet za menadžment, Njegoševa 1a, 21205 Sremski Karlovci, e-mail: tijanastot@gmail.com

${ }^{2}$ Fakultet za menadžment, Njegoševa 1a, 21205 Sremski Karlovci, e-mail:m.runicristic@gmail.com

${ }^{3}$ Fakultet za menadžment, Njegoševa 1a, 21205 Sremski Karlovci, e-mail: s.adzic@famns.edu.rs
} 
business activities, have different legal forms and the number of employees. Finally, the results of the study represent the basis for both its improvement and for further research within different industries.

Keywords: employee selection process, characteristics of a selection process, Central Serbia

\section{INTRODUCTION}

Numerous research in the field of human resource management proves that employees have a key role in enhancing organizational performance (Boxall, Purcel, 2016, Torringhton, Hall, Taylor, 2020). Therefore, it resulted in the development of models (Fombrun, et. al. 1982, Beer, et al., 1984) and human resource management processes (Torringhton, Hall, Taylor, 2014; Armstrong, 2014, Dessler, 2019) whose goals were changed over time depending on the changes in the external environment. The first human resource management models and processes were designed to create more efficient employee management and to reduce labor costs (Lepak et al., 2006; Liao et al., 2009). Later models and processes were developed to increase the organization's performance (Tyson, 2015). Nowadays, their aim is in developing a highly talented and qualified workforce in order to gain a competitive advantage (Torringhton, Hall, Taylor, 2020). Human resource selection was a crucial element within the development of human resource management and it involved the development from an individual activity aimed at fitting employees with job requirements, through defining and creating a process aimed at increasing employee productivity and performance to harmonizing processes with the strategic needs of the organization (Lievens, Sackett, Zhang, 2020) Employee selection is probably one of the most important processes in organizations because its primary goal is to select those candidates who will fit not only to the requirements of a job but also to organizational culture (Sacket, et al, 2017). With the selection of the most talented employees, the organizations increase their ability to achieve strategic goals and to manage changes more efficiently (Compton, Morrisey, Nankervis 2009) There are numerous studies on the influence of employee selection on the increase of employee performance (Fulmer, Ployhart, 2014; Lepak et al., 2012; Ployhart, 2012b, 2012a; Renkema et al., 2016; Sutanto, 
Kurniawan, 2016; Rafii, Andri, 2015) as well as on its influence on the increase of employee commitment, work quality and work success (Boxall, Purcell, 2015, Patimah, 2015). Thus, organizations are increasingly devoted to identifying appropriate employee selection processes. However, although the selection process is considered crucial in human resource management, very little research has been focused on the characteristics of the process itself (Zysberg, Nevo, 2004). Most studies have been focused on the development and testing of the appropriate tools that increase the efficiency and effectiveness of the selection process (Ployhart et al., 2017; Sackett, Lievens, 2020; Sackett et al., 2017). As a result, knowledge of the characteristics of the process in organizations is limited and it is very difficult to assess how the selected tools will improve the selection process in organizations in different industries, with a different number of employees, etc. (Ryan, Tippins, 2004). In the Republic of Serbia, one of the most systematized surveys of the selection process was conducted as a part of CRANET survey in 2008 and 2015 in 158 organizations with more than 50 employees. The results of these surveys indicate that recruitment and selection strategy exists in only $50 \%$ of the surveyed organizations and that in most of these organizations (about $80 \%$ ) the line managers alone or in collaboration with the human resource department decide on the activities of the selection process. If the selection process is not properly conducted, it will not lead to increasing organizational performance and achieving competitive advantage. Selection processes that are aligned with organizational goals and needs can affect $60 \%$ of performance variations (Salgado, 2017). Considering the above-mentioned facts, the authors wanted to examine the employee selection process in organizations in Central Serbia focusing on the characteristics of the process itself to show its deficiencies and to propose measures for its improvement. Taking into account the results of Purcell and Boxall's (2015) research which defines the characteristics of the employee selection process in organizations that have different business activities, legal forms and number of employees, the authors wanted to examine whether there are differences in the employee selection process in organizations in Central Serbia. Moreover, the authors wanted to define the characteristics of the employee selection process that may represent the basis for further research within different industries and business activities. 


\section{SCIENTIFIC CONSIDERATIONS AND LITERATURE REVIEW}

\subsection{Definition of the concept of human resource selection}

Armstrong (2014) defines the selection process as a set of activities designed to make a selection between the available candidates for a certain job and to make a decision regarding their employment or rejection, while the author Torringhton et al (2020) defines selection as a procedure which applies predetermined and standardized methods and techniques and selects those who best meet the requirements of a certain job. Moreover, Torringhton's et al., (2020) definition of the selection process emphasizes the job analysis as the foundation for defining the criteria for selecting the right candidate. She also stresses the importance of predefined methods and techniques that are unique for each organization. According to Torringhton et al., (2020) the purpose of the well-designed and systematic selection process is to increase both employees and organizational performance and, therefore, to lead to achieving organizational goals.

The effective selection process aims to achieve, as much as possible, compliance between job requirements and candidate's characteristics, i.e. to identify those candidates whose potential, competencies, and personality would be fully aligned with job requirements (Noe, et al., 2020)

\subsection{Defining selection criteria and candidate specifications}

The first step in the selection process is defining selection criteria and candidate's specifications. If the criteria by which candidates are categorized are not clear, it is impossible to make reliable decisions. Selection criteria are typically displayed as specifications, i.e. a description of a person who represents the ideal candidate. Lewis, C., (1985) distinguishes three selection criteria:

a) organizational criteria - are those characteristics of employees valued by the organization,

b) departmental criteria - for example, defining the appropriate interpersonal skills of all members of the human resource department, or marketing department, research and development department, etc. 
c) individual job criteria - are part of a job description and person specifications, and they are derived from the process of job analysis.

To define these criteria the cooperation of a team of experts (a member of the human resource sector, a member of the sector seeking an employee, a member of top management, and a psychologist) is required.

\subsection{Selection methods}

The second step in the selection process is to choose a selection method. The purpose of choosing the right method is not only to collect information that will predict an individual's work success but also to determine the degree of compliance between job requirements and individual characteristics of potential candidates (Torrington, et. al., 2014)

Identifying the right method will depend on the job, i.e. workplace for which we select candidates, general policy and employment strategy, the expertise of people in human resources, philosophy and attitudes of the management, etc. Gathered information and chosen methods are the basis for deciding on the process of selecting candidates. We can divide selection methods and data collection sources into two groups. The first one is conventional which includes a job application letter, biography, certificates and diplomas, recommendations, psychological tests, interviews, job sample tests, a probation period, situational tests, assessment centers, and medical examinations. The second one is unconventional and it includes polygraph analyses, graphological analyses, drug testing, etc. Depending on the factors and criteria that are explicitly determined and defined by the organization, the selection of the appropriate selection methods and sources of information is made. A combination of methods is usually used for the selection process and it is usually determined in compliance with the job, time, administrative incentives, costs, accuracy, and ability of the staff in charge of the selection. The effective selection process aims to achieve, as much as possible, compliance between job requirements and candidate's characteristics, i.e. to identify those candidates whose potential, competencies, and personality would be fully aligned with job requirements (Noe, et al., 2020). 
According to Torrington, et al., (2020), the most common and important selection methods are:

a) Application forms - they make sorting of applications and shortlisting candidates easier and enable interviewers to use the form as the basis for the interview process.

b) Self-assessment - There is an increasing interest in providing more information to applicants about the job through informal discussions, video presentations, or by sending information with an application form. This approach allows candidates to become familiar with realistic job descriptions and assess their suitability accordingly.

c) Telephone interviewing - data gathering through telephone interviewing can be used instead of application forms if the time is of the utmost importance or if the candidate is geographically distant. This method works best if there is a preprepared list of questions so that standardized information is obtained from each candidate.

d) Testing - The opinions about the use of tests in employment procedures are divided. The ones, who consider that tests are necessary, emphasize that an interview is unreliable. On the other hand, those, who believe that tests are not necessary, point out that it is very complicated to incorporate test results with other results (Ployhart, 2017). Nevertheless, the use of testing for the selection process has increased. In $199775 \%$ of organizations used general ability tests, and $60 \%$ used personality tests (Torrington, et. al., 2020). Tests are an instrument for measuring the candidate`s skills and knowledge, abilities, and various traits. There are different types of tests, and the most important are: general intelligence tests, aptitude tests, interest tests, and personality tests. Most of these tests involve the principle of paper-pencil, i.e. consist of written material. However, some tests include specific instruments that are used to examine certain abilities, such as sensory and psychomotor. For any of these forms of testing to have real value, it must possess metric characteristics - validity, objectivity, reliability, sensitivity, and usability.

e) Group selection methods - are used when the organizations wish to determine how will the potential candidate get along 
with colleagues, how do they think about specific problems, resolve conflicts, etc.,

f) Assessment centers - are used to evaluate future employee performance based on several selection methods. The activities can include interviews, problem-solving exercises, group discussions, and business decision-making games. Assessment centers have and predicting the later work performance of those in managerial positions.

g) Interview - According to Plumbley, P. R., (1985) interview can be defined as a targeted conversation that examines whether a candidate is capable of doing the job that he has applied for. During the interview, the organizations try to obtain adequate information about a candidate such as individual potential, job interest, ability to influence others, but also to provide the candidate with information about the job and the company. The interviewer must establish trust and understanding between himself and the candidate. The aim of interviewing process is to obtain information about a candidate and to assess whether he is suitable for the job. Therefore, most authors believe that this process should include the following steps (Noe et al., 2020): providing basic information about the candidate's working experience, providing information about the job requirements, planning where the interview will take place, designing the main questions from the planned areas, conducting the interview and processing results obtained through the interview.

What needs to be considered is that there is no perfect selection method. At best, designing activities within the selection process provides organizations with the opportunity to predict more accurately the future performance of the employees. Thus, selection can be seen as a process that helps organizations to avoid hiring inadequate candidates (Ployhart, 2017).

\subsection{Final selection decision making}

The selection decision is the ultimate step in the process. It implies that the characteristics of a candidate should be compared to selection 
criteria. Furthermore, making a final decision is a critical stage of the selection process since a choice must be made between many candidates who applied for the job. Therefore, for the final selection decision making it is very important what the candidate can and what the candidate wants since these two factors directly affect the candidate's performance.

\section{RESEARCH}

Based on the defined theoretical framework, the paper aims to study the characteristics of the employee selection process in organizations in Central Serbia. The problem of the research is to identify differences in the employee selection process among organizations that have different business activities, legal forms, and the number of employees. Based on the previously formulated problem and research objectives, the main hypothesis was established:

H0: In the employee selection process there are statistically significant differences in relation to the characteristics of the organization.

The following hypotheses are defined according to the main hypothesis:

H1 There are statistically significant differences in the employee selection process between manufacturing and service organizations

H2 There are statistically significant differences in the selection process between public and private organizations

H3 There are statistically significant differences in the selection process in relation to the number of employees in the organizations

The research aimed to define the characteristics of the employee selection process in the examined organizations and to make suggestions for their improvement.

The questionnaire used in this research was designed to investigate the whole process of human resource management, while this research shows only the results related to the employee selection process (Savić Tot T., PhD dissertation). Considering the theoretical framework, a questionnaire was developed to analyze the criteria and methods of the employee selection process. The questionnaire consisted of a five-point Likert scale in which respondents, by circling one of the offered 
alternatives, state the degree of agreement or disagreement with the items. Also, there are closed-ended questions and respondents were able to choose one or more offered answers or to write down the answer that was not provided by the questionnaire. The Alpha coefficient was applied to confirm the reliability of the questionnaire. Considering that the reliability range of the Alpha coefficient ranges from 0 to 1 , we can conclude that the reliability of the questionnaire is high.

Independent variables refer to the characteristics of the organization: business activities - manufacturing and service, legal forms of the organization - private and public, and the number of the employees in the organizations (small - up to 50 employees, medium - from 50 to 250 employees, and large - over 250 employees). Dependent variables relate to the key activities of the selection process in organizations.

The research included 127 respondents who are employed at all three management levels in the organization (top management, middle management, and the first-line management) in 86 organizations in Central Serbia (Rasina District). 46,03\% of respondents are from manufacturing and 53,97\% from service organizations and 38,6\% of respondents are from public organizations and 61,4\% from private. 7,1\% of respondents work in organizations with 10 employees, 48,4\% of respondents work in organizations with between 10 and 50 employees, $17,5 \%$ of respondents work in organizations with between 50 and 250 employees and $27 \%$ of respondents work in organizations with more than 250 employees.

Statistical methods that were used included: Mann-Whitney U Test - U test is equivalent to the parametric t-test, because it compares two groups of data, via a median, Spearman's rank correlation - is used to measure the relationship between variables in cases where it is not possible to apply Pearson's correlation coefficient. It is based on measuring the consistency of the association between variables, and the form of association, Pearson's chi-square test $-\chi^{2}$ distribution is used in scientific research to determine whether a distribution of the obtained measurement results significantly deviates from another distribution or coincides. 


\subsection{Research results}

With the analysis of the selection process activities in relation to the characteristics of the organizations - business activity, legal form, and number of employees in the organization, the following results were obtained:

\section{a) In relation to the business activity of the organization}

Mann -Whitney U Test found that respondents employed in service organizations rated the following selection activities higher than the respondents employed in manufacturing organizations:

- Knowledge tests are used in your organization for employee selection $(\mathrm{U}=1662.50, \mathrm{z}=-2.312, \mathrm{p}<0.05)$,

- Personality tests are used in your organization for employee selection $(\mathrm{U}=17800, \mathrm{z}=-2.111, \mathrm{p}<0.05)$.

Table 1. Testing the differences between respondents employed in manufacturing and service organizations regarding the selection activities process using Mann-Whitney U Test

\begin{tabular}{ccc}
\hline \hline & $\begin{array}{c}\text { Mann-Whitney } \\
\mathrm{U}\end{array}$ & $\mathrm{Z}$ \\
\hline \hline $\begin{array}{c}\text { Knowledge tests are used in your organization for } \\
\text { employee selection }\end{array}$ & 1662.500 & $-2.312 .021^{*}$ \\
\hline \hline $\begin{array}{c}\text { Personality tests are used in your organization for } \\
\text { employee selection }\end{array}$ & 1780.000 & $-2.111 .035^{*}$ \\
\hline \hline
\end{tabular}

a. Group variable: the type of business activity

Legend *Significance on the level lower than $0.05^{* *}$ Significance on the level lower than 0.01 
Table. 2. Average rankings for variables where a significant difference was observed in the selection process activities in manufacturing and service organizations

\begin{tabular}{ccccc}
\hline \hline & Type of activity & $\mathrm{N}$ & $\begin{array}{c}\text { Average } \\
\text { Rank }\end{array}$ & Rank sum \\
\hline Knowledge tests are used in & Manufacturing & 58 & 58.16 & 3373.50 \\
your organization for & Service & 69 & 68.91 & 4754.50 \\
employee selection & Total & 127 & & \\
\hline Personality tests are used in & Manufacturing & 58 & 60.19 & 3491.00 \\
your organization for & Service & 69 & 67.20 & 4637.00 \\
employee selection & Total & 127 & & \\
\hline
\end{tabular}

Pearson-s $\chi^{2}$ test showed differences between the respondents employed in manufacturing and service organizations regarding the person interviewing the candidates $\left(\chi^{2}=13.526, p<0.01\right)$, in manufacturing organizations it is a human resource director, while in service organizations it is a team of experts. Pearson's $\chi^{2}$ test found no differences between the respondents employed in manufacturing and service organizations referring to the fact who makes the final decision on the employee selection and who creates job adverts.

Table 3. Testing the differences in implementing human resource selection process activities between the respondents employed in manufacturing and service organizations by using Pearson's $\chi^{2}$ test

\begin{tabular}{ccc}
\hline \hline & & type of activity \\
\hline Interview with candidates is conducted by & $\chi^{2}$ & 13.526 \\
& $\mathrm{Df}$ & 3 \\
The final decision on the employee selection is & $\mathrm{P}$ & $.004^{*}$ \\
made by & $\chi^{2}$ & 1.343 \\
& $\mathrm{Df}$ & 3 \\
\hline & $\mathrm{P}$ & .719 \\
\hline Job adverts in your organization are created by & $\chi^{2}$ & 2.428 \\
& $\mathrm{Df}$ & 3 \\
\hline \hline
\end{tabular}

Legend *Significance on the level lower than 0.05 
Table 4. Cross tabulation with a display of response distribution depending on the type of business activity of the organization regarding the human resource selection activities.

\begin{tabular}{|c|c|c|c|c|c|}
\hline & & \multicolumn{4}{|c|}{ type of activity } \\
\hline & & \multicolumn{2}{|c|}{ Manufacturing } & \multicolumn{2}{|c|}{ Service } \\
\hline & & Count & Column N \% & Count & Column N \% \\
\hline \multirow{4}{*}{$\begin{array}{l}\text { Interview with the } \\
\text { candidates is } \\
\text { conducted by }\end{array}$} & Director & 22 & $37.9 \%$ & 24 & $34.8 \%$ \\
\hline & $\begin{array}{c}\text { Human resource } \\
\text { director }\end{array}$ & 11 & $19.0 \%$ & 1 & $1.4 \%$ \\
\hline & $\begin{array}{l}\text { Immediate } \\
\text { superior }\end{array}$ & 10 & $17.2 \%$ & 13 & $18.8 \%$ \\
\hline & Team of experts & 15 & $25.9 \%$ & 31 & $44.9 \%$ \\
\hline
\end{tabular}

For other activities, Mann-Whitney $\mathrm{U}$ Test and chi-square test did not identify significant differences between respondents employed in manufacturing and service organizations.

\section{b) In relation to the legal form of organization}

Mann -Whitney $U$ test found that the respondents employed in public organizations rated the following selection activities with higher grades and degree than the respondents employed in private organizations:

- Job applications review in your organization is conducted by a team of experts $(\mathrm{U}=1620.000, \mathrm{z}=-2.034, \mathrm{p}<0.05)$,

- Knowledge tests are used in your organization for employee selection $(\mathrm{U}=1493.000, \mathrm{Z}=-2.921, \mathrm{p}<0.01)$,

- Personality tests are used in your organization for employee selection $(\mathrm{U}=1633.000, \mathrm{Z}=-2.713, \mathrm{p}<0.01)$,

while the respondents employed in private organizations rated higher the following activities:

- Candidates who are the best match with job requirements are selected in your organization $(U=1229.000, Z=-3.600, p<0.05) i$

- The review of job applications in your organization is conducted by the director ( $U=1695.000, Z=-1.972, \mathrm{p}<0.01)$. 
Table 5. Testing the differences between the respondents employed in public and private organizations in application of human resource selection activities using Mann-Whitney $U$ Test

\begin{tabular}{|c|c|c|c|c|}
\hline \multirow{3}{*}{\multicolumn{2}{|c|}{$\begin{array}{l}\text { Candidates who are the best match with job } \\
\text { requirements are selected in your organization } \\
\text { Job applications review in your organization is } \\
\text { conducted by a team of experts }\end{array}$}} & $\begin{array}{c}\text { Mann-Whitney } \\
\text { U }\end{array}$ & $\mathrm{Z}$ & $\mathrm{p}$ \\
\hline & & 1229.000 & -3.600 & $.000^{*}$ \\
\hline & & 1620.000 & -2.034 & $.042^{*}$ \\
\hline $\begin{array}{l}\text { Job applications review in your organi } \\
\text { conducted by the director }\end{array}$ & ization is & 1695.000 & -1.972 & $.049 *$ \\
\hline $\begin{array}{c}\text { Knowledge tests are used in your organ } \\
\text { employee selection }\end{array}$ & ization for & 1493.000 & -2.921 & $.003^{* *}$ \\
\hline $\begin{array}{c}\text { Personality tests are used in your organ } \\
\text { employee selection }\end{array}$ & ization for & 1633.500 & -2.713 & $.007^{* *}$ \\
\hline \multicolumn{5}{|c|}{$\begin{array}{l}\text { Table 6. Average rankings of selection process activities with the significant } \\
\text { difference for manufacturing and service organizations }\end{array}$} \\
\hline & $\begin{array}{c}\text { the legal } \\
\text { form of } \\
\text { organizatior }\end{array}$ & $\mathrm{N}$ & $\begin{array}{l}\text { Average } \\
\text { ranks }\end{array}$ & Rank sum \\
\hline \multirow{3}{*}{$\begin{array}{c}\text { Candidates who are the best match } \\
\text { with job requirements are selected in } \\
\text { your organization }\end{array}$} & State & 49 & 50.08 & 2454.00 \\
\hline & Private & 76 & 71.33 & 5421.00 \\
\hline & Total & 125 & & \\
\hline \multirow{3}{*}{$\begin{array}{c}\text { Job applications review in your } \\
\text { organization is conducted by a team of } \\
\text { experts }\end{array}$} & State & 49 & 69.94 & 3427.00 \\
\hline & Private & 78 & 60.27 & 4701.00 \\
\hline & Total & 127 & & \\
\hline \multirow{3}{*}{$\begin{array}{l}\text { Job applications review in your } \\
\text { organization is conducted by the } \\
\text { director }\end{array}$} & State & 49 & 59.59 & 2920.00 \\
\hline & Private & 78 & 66.77 & 5208.00 \\
\hline & Total & 127 & & \\
\hline \multirow{3}{*}{$\begin{array}{l}\text { Knowledge tests are used in your } \\
\text { organization for employee selection }\end{array}$} & State & 49 & 72.53 & 3554.00 \\
\hline & Private & 78 & 58.64 & 4574.00 \\
\hline & Total & 127 & & \\
\hline \multirow{3}{*}{$\begin{array}{l}\text { Personality tests are used in your } \\
\text { organization for employee selection }\end{array}$} & State & 49 & 69.66 & 3413.50 \\
\hline & Private & 78 & 60.44 & 4714.50 \\
\hline & Total & 127 & & \\
\hline
\end{tabular}




\section{c) In relation to the number of employees in the organization}

Spearman rank correlation found that the respondents in organizations with a larger number of employees ranked higher the following selection activity:

- General intelligence tests are used for employee selection $\left(\rho_{S}=.230^{*}\right.$, $\mathrm{p}<0.05)$

Table 7. The correlation between human resource selection process activities and the number of employees in the organization determined by Spearman rank correlation

\begin{tabular}{ccc}
\hline & & $\begin{array}{c}\text { Number of employees in your } \\
\text { organization }\end{array}$ \\
\hline $\begin{array}{c}\text { General intelligence tests are used in } \\
\text { your organization for employee } \\
\text { selection }\end{array}$ & $\rho_{\mathrm{s}}$ & $.230^{* *}$ \\
\cline { 2 - 3 } \begin{tabular}{c}
$\mathrm{p}$ \\
\cline { 2 - 3 } \begin{tabular}{c} 
s. \\
\cline { 2 - 3 }
\end{tabular}
\end{tabular} & $\mathrm{N}$ & 0.009 \\
\hline
\end{tabular}

Legend *Significance on the level lower than $0.05^{* *}$ Significance on the level lower than 0.01

\section{DISCUSSION}

By analyzing the differences in relation to the business activities of organizations, we identified that there are statistically significant differences that indicate that knowledge and personality tests are applied more in service organizations and that the interview with the candidates is conducted by a team of experts comparing to manufacturing organizations. Therefore, we can conclude that the first hypothesis of the paper is confirmed. The fact that different selection methods are used in service organizations is not surprising considering that a higher level of knowledge is required for professions in a service sector, and employees need to achieve a higher quality of service to achieve a higher service price (Cook, 2014). This also includes greater investment in human resource management processes, particularly employee recruitment and selection (Fabling, Grimes, 2010). However, it 
is necessary to examine whether these methods are appropriate for certain jobs which include examining the process of job analysis and systematization of jobs as well as their adjustment with selection criteria (Lewis, 1985). Only after the previous two steps are conducted, we can evaluate if the appropriate selection methods have been selected. In manufacturing organizations, statistically significant differences show that the interview is the selection method that is mostly used and it is conducted by the human resource director contrary to service organizations where it is conducted by a team of experts. This result indicates the higher-level quality of the selection process in service organizations because a team of experts involves cooperation and participation of human resource managers, immediate superior, and general director. Moreover, it includes defining selection criteria at all three levels (organization, department, and individual job criteria). On the other hand, in manufacturing organizations, since the interview is the only selection method, it will not provide a high-quality candidate that will fulfill the requirements of the job and the organization. It has been noticed that considering the level of the development of technology, service organizations invest more resources in strengthening human resource management processes, especially recruitment and selection, as well as the development of employees, while they don't see a purpose in developing specific processes in the organizations where less advanced technology is applied in the production process (Fabling and Grimes, 2010). Considering everything mentioned above, we suggest that, in manufacturing organizations, attention should be focused on combining various selection methods, i.e. the combination of tests and interviews should be used and immediate superiors should be included in the candidate selection process.

By analyzing the second hypothesis of the research which relates to statistically significant differences in the selection process between public and private organizations, the results show that in public organizations knowledge tests and personality tests are used as selection methods and that the job applications review is conducted by a team of experts, while in private organizations the dominant method is the interview conducted by the director. Therefore, we can conclude that our second hypothesis is confirmed. Since public organizations are financed by the state, in most cases they have more employees, they are more 
bureaucratic and depend on the economic and political situation in a particular state (Freeman, Boxall, Haynes, 2007) and the selection process is more formalized. However, attention should be aimed at synchronizing selection criteria with methods to ensure a better quality of the process. In private organizations, the results show that the candidates who best meet the job requirements are chosen and that the job application review is conducted by the general director. Contrary to public organizations, private organizations are market-oriented and have fewer employees, so the selection activities are conducted by a general director or an owner of an organization. Since private organizations depend on the achieved profit, candidates who meet job requirements can be a direct consequence of it (Purcell, Boxall, 2015)

The third hypothesis which refers to statistically significant differences in the selection process among organizations with a different number of employees is partially confirmed. Except for the use of general intelligence tests in organizations with more employees, there were no statistically significant differences. Numerous researches show that more employees in the organization lead to a higher level of formalization of the human resource management selection process (Boxall, Purcell, 2015) which was not shown in the surveyed organizations.

The analysis of the selection process in the surveyed organizations indicates that the review of job applications in most organizations is conducted by the legal department, which is not surprising considering that in a great number of organizations there are no human resource departments (Savić Tot, Tot, 2020). Although knowledge tests, personality tests, and general intelligence tests are used in organizations, the question is whether the criteria of knowledge and personality are recognized and defined within the systematization of jobs (Savić Tot, 2016; Savić Tot, Tot, 2019). Position advertisements in most organizations are created by legal departments, the review of job applications is conducted by the director, and the final decision on the selection of candidates is made by the general director which affects the limited quality and objectivity of the selection process in the examined organizations. Nevertheless, it is encouraging that in these organizations the review of job applications is conducted by a human resource department and that it makes the final decision on the selection of candidates which is the initial step in creating a well-designed selection 
process. In the analysis of the applied activities within the human resource selection process in relation to independent variables, the results show that there are statistically significant differences that determine the characteristics of the selection process in the examined organizations confirming the main hypothesis of the research study. The following characteristics of the selection process were singled out: The candidates who best fit to job requirements are selected, The review of job applications is conducted by the legal department, human resource department, and the director of the organization, Knowledge tests, personality tests, and general intelligence tests are used while selecting employees, The advertisements are created by the legal department and The final decision on employee selection is made by a general director and human resource department director.

\section{CONCLUSION}

Based on the analysis of the relevant literature and the results of this research, it can be concluded that the employee selection process is done in all organizations regardless of their business activity and size. Although the hypotheses of this study have been confirmed, designing the selection process according to the needs of an organization has not been sufficiently developed yet and, therefore, it cannot contribute to the increase of the organizational performance. Such results are not surprising when we consider that only half of organizations in Serbia have the employee recruitment and selection strategy (CRANET report 2015).

It is also not clear to what extent a designed recruitment and selection strategy is aligned with organizational goals and strategy. Our research may serve as the basis for a more detailed study on the employee selection process among different industries to enable the application and adoption of good practices. Furthermore, characteristics and differences of the employee selection process could be defined since it has been shown that organizations that belong to the same industry tend to adopt faster processes that are more effective (Boxall, Purcell, 2015). 


\section{REFERENCES:}

1. Armstrong, M.,Taylor, S. (2014) Armstrong's Handbook of Human Resource Management Practice, 13th Edition.; Kogan Page Ltd: Philadelphia, PA,

2. Beer, M., Spector, B., Lawrence, D., Walton, R. E., (1984). Managing Human Assets, Free Press, New York

3. Dessler, G. (2019). Human Resources Management, Global Edition; Pearson,

4. Fabling, R.; Grimes, A. (2010). HR Practices and New Zealand Firm Performance: What Matters and Who Does It? Int. J. Hum. Resour. Manag. 21 (4), 488-508, https://doi.org/10.1080/09585191003611994

5. Fombrun, C. J., Tichy N., (1982). Strategic planning and human resource management, Division of Research, Graduate School of Business Administration, University of Michigen

6. Freeman, R. B.; Boxall, P. F.; Haynes, P., (2007). P. What Workers Say: Employee Voice in the Anglo-American Workplace; Cornell University Press: Ithaca and London

7. Fulmer, I., Ployhart, E.R., (2014) Our Most Important Asset": A Multidisciplinary/Multilevel Review of Human Capital Valuation for Research and Practice, Journal of Management, https://doi.org/10.1177/0149206313511271

8. Lepak, D.; Liao, H.; Chung, Y.; Harden, E. A (2006). Conceptual Review of Human Resource Management Systems in Strategic Human Resource Management Research. 25, 217-271, https://doi.org/10.1016/S0742-7301(06)25006-0

9. Lepak, P.D., Jiang, K., Kyongji, H., Hong, Y., (2012). Clarifying the construct of human resource systems: Relating human resource management to employee performance, Human Resource Management Review, vol.22, issue 2., pp.73-85, https://doi.org/10.1016/j.hrmr.2011.11.005

10. Lewis, C., (1985). Employee selection. London: Hutchinson.

11. Liao, H., Keiko, T., Lepak, P.D., Ying, H., (2009). Do they see eye to eye? Management an employee perspectives of high performance work systems and influence processes on service quality, Journal of Applied Psychology, 94(2), 371-391., https://doi.org/10.1037/ a0013504 
12. Lievens, F., Sackett, P., Zhang, C., (2020). Personnel selection: a longstanding story of impact at the individual, firm, and societal level, European Journal of Work and Organizational Psyhology, https://doi.org/10.1080/1359432X.2020.1849386

13. Nankervis, A.; Compton, R.; Baird, M.; Coffee, J. (2011). Human Resource Management: Strategy and Practice, Cangage

14. Noe, R.; Hollenbeck, J.; Gerhart, B.; Wright, P. (2020). Human Resource Management, 12th edition.; McGraw-Hill Education,

15. Patimah, S., (2015) Transformative Leadership for Improving the Quality of Indonesian Islamic Universities, Proceedings of the $1^{\text {st }}$ raden intan international conference on muslim socities and social science, https://doi.org/10.2991/assehr.k.201113.026

16. Ployhart, R. E. (2012a). Multilevel selection and the paradox of sustained competitive advantage. In Oxford library of psychology. In N. Schmitt (Ed.), The Oxford handbook of personnel assessment and selection. Oxford University Press.

17. Ployhart, R. E. (2012b). The psychology of competitive advantage: An adjacent possibility. Industrial and Organizational Psychology, 5(1), 62-81. https://doi.Org/10.1111/j.1754-9434.2011.01407.x

18. Ployhart, R. E., Schmitt, N., Tippins, N. T. (2017). Solving the supreme problem: 100 years of selection and recruitment at the journal of applied psychology. The Journal of Applied Psychology, 102(3), 291-304. https:// doi.org/10.1037/apl0000081

19. Plumbley, P. R., (1985)..Recruitment and Selection. Institute of Personnel Management

20. Purcell, J.; Boxall, P. (2015). Strategy and Human Resource Management (Management, Work, Organizations), 4th ed. Red Globe Press: London ; New York,

21. Rafii, M., Andri, S., (2015). The influence of employee recruitment and placement on employee performance on PT. Bank, Online Journal of Indonesia Faculty of Social and Political Sciences, 2(1), $1-12$.

22. Renkema, M., Meijerink, J., \& Bondarouk, T. (2016). Advancing multilevel thinking and methods in HRM research. Journal of Organizational Effectiveness: People and Performance, 3(2), 204218. https://doi.org/10. 1108/JOEPP-03-2016-0027

23. Ryan, M, Tippins, N.P., (2004). Attracting and selecting: What psychological research tells us, Human Resource Management, 
Volume 43, Issue 4 p. 305-318, https://doi.org/10.1002/ hrm.20026

24. Sackett, P. R., Lievens, F., Van Iddekinge, C. H., \& Kuncel, N. R. (2017). Individual differences and their measurement: 100 years of research in the journal of applied psychology. Journal of Applied Psychology, 102(3), 254-273. https://doi.org/10.1037/apl0000151

25. Salgado, J., (2017) Personality in Personnel Selection, The Blackwell Handbook of Personnel Selection, Chapter 3., https://doi.org/10.1002/9781405164221.ch8

26. Savić Tot, (2016). Doctoral thesis, Development of Strategic human resource management model in gaining competitive advantage, FTN, University Novi Sad

27. Savić Tot, T., Tot, V., (2019): Strategijski menadzment ljudskih resursa kao elemenat konkurentske prednosti $u$ odnosu na karakteristike procesa analiza posla, monografija Strategijski menadžment ljudskih resursa kao elemenat konkurentnosti, Fakultet za pravne i poslovne studije Beograd, knj. 2. - str. 21-85, Beograd

28. Savić Tot, Tot, V., (2020). Osobenosti procesa razvoja ljudskih resursa u organizacijama u Centralnoj Srbiji, Ekonomija - Teorija i praksa, vol.12., no.4., pp.1-17

29. Sutanto, E., Kurniawan, M., (2016). The impact of recruitment, employee retaniation and relations to employee performance on batik industry in solo city, Indonesia, International Journal of Business and Society, 17 (2), pp. 375-390.

30. Torrington, D. (2014). Human Resource Management, 9th edition.; Trans-Atlantic Publications: Harlow

31. Torrington, D.; Hall, L.; Taylor, S.; Atkinson, C. (2020). Human Resource Management, 11th Edition, 11th edition.; Pearson: Harlow, England; New York,

32. Tyson, S. (2015). Essentials of Human Resource Management, 6th edition.; Routledge: New York,

33. Zysberg, L., Nevo, B., (2004). The Smarts That Counts: Psyhologists Decision-Making in Personnel Selection, Journal of Business Psyhology, 19., pp.117-124., https://doi.org/10.1023/B:JOBU.0000040275.16133.15 


\title{
ANALIZA PROCESA SELEKCIJE ZAPOSLENIH U ORGANIZACIJAMA CENTRALNE SRBIJE
}

\author{
Tijana Tot Savić
}

\author{
Marija Ristić Runić
}

Slobodan Adžić

Sažetak: Kako proces selekcije zaposlenih predstavlja jedan od najosetljivijih procesa menadžmenta ljudskih resursa, koji ima za cilj odabir zaposlenih koji najviše odgovaraju potrebama organizacije, autori su predmet istraživanja rada usmerili na ispitivanje karakteristika procesa selekcije zaposlenih u organizacijama Centralne Srbije. U odnosu na predmet rada, definisan je problem istraživanja koji se odnosi na ispitivanje razlika u procesu selekcije između organizacija različite delatnosti, vlasništva i broja zaposlenih. Osnovna hipoteza rada, koja je rezultatima i potvrđena, jeste da postoje statistički značajne razlike koje ukazuju na specifičnosti procesa selekcije zaposlenih $u$ ispitivanim organizacijama. $U$ realizaciji istraživanja korišćen je upitnik u čijoj obradi su primenjene brojne statističke metode. Rezultati istraživanja, između ostalog, ukazuju na nedostatke u procesu selekcije zaposlenih, kao i na ispitivane razlike $u$ odnosu na delatnost, vlasništvo i broj zaposlenih $i$ predstavljaju osnovu kako za njegovo unapređenje tako $i$ za dalja istraživanja u okviru različitih industrija sa ciljem definisanja njihovih specifičnosti.

Ključne reči: proces selekcije zaposlenih, karakteristike procesa selekcije, Centralna Srbija. 